\section{Follow-up after very preterm birth in Europe}

Follow-up programmes aim to detect neurodevelopmental and health problems and enable early interventions for children born very preterm ( $<32$ weeks of gestational age $(\mathrm{GA}))$. Although the importance of postdischarge follow-up is widely acknowledged, recommendations differ regarding eligibility criteria, frequency, duration and content, especially for follow-up beyond early childhood. ${ }^{1-3}$ We used data from a European cohort of children born very preterm to describe the use of routine follow-up services until 5 years of age.

The data were collected for the Effective Perinatal Intensive care in Europe and Screening to Improve Health in Very Preterm Infants studies, which constituted and followed up an area-based cohort of children born very preterm in 2011/2012 in 19 regions across 11 European countries. ${ }^{4}$ Perinatal data were collected from obstetric and neonatal records, and parents completed questionnaires at 2 and 5 years of age. Out of 7900 live births, 6792 were discharged from neonatal care, of whom 6759 were alive at 5 years and 3635 (53.8\%) participated in the study.

Based on a question on the use of routine follow-up services for children born very preterm in the 5 -year parental questionnaire, we classified children as having never used follow-up, no longer using follow-up or still using follow-up services. We described associations with family sociodemographic characteristics and perinatal risks and estimated adjusted risks using multinomial regression models with robust variance estimators for clustered samples and inverse probability weights using baseline characteristics to account for study attrition bias. ${ }^{4}$

Of all children, $90.3 \%$ had used follow-up services, and $27.3 \%$ (10.9 to $58.4 \%$ by country) were still doing so at 5 years of age (table 1). Never using follow-up services was associated with maternal sociodemographic characteristics (younger age, low educational level and being born outside Europe) and lower perinatal risk. Continued follow-up at 5 years of age was related to perinatal risk factors (low GA, small for GA, bronchopulmonary dysplasia and male sex). Children with mothers born outside of Europe were less likely to continue follow-up. Adjustments for social and perinatal characteristics failed to explain differences between countries.

Table 1 Family sociodemographic and perinatal factors associated with routine follow-up for children born very preterm, at 5 years of age

\begin{tabular}{|c|c|c|c|c|c|c|c|c|}
\hline \multirow{3}{*}{$\begin{array}{l}\text { Does child have routine check-ups for children } \\
\text { born very preterm at } 5 \text { years? }\end{array}$} & \multirow{3}{*}{$\mathrm{N}$} & \multirow{3}{*}{$\begin{array}{l}\begin{array}{l}\text { No, } \\
\text { never }\end{array} \\
\%\end{array}$} & \multirow{3}{*}{$\begin{array}{l}\begin{array}{l}\text { Not } \\
\text { anymore }\end{array} \\
\%\end{array}$} & \multirow{3}{*}{$\begin{array}{l}\begin{array}{l}\text { Yes, } \\
\text { still }\end{array} \\
\%\end{array}$} & \multicolumn{4}{|c|}{ Reference: still in follow-up at 5 years } \\
\hline & & & & & \multicolumn{2}{|c|}{ No, never } & \multicolumn{2}{|c|}{ Not anymore } \\
\hline & & & & & aRRR & $95 \% \mathrm{Cl}$ & aRRR & $95 \% \mathrm{Cl}$ \\
\hline \multicolumn{9}{|l|}{ Mother's age at delivery (years) } \\
\hline$\leq 24$ & 422 & 17.3 & 55.2 & 27.5 & 2.0 & 1.2 to 3.5 & 1.1 & 0.8 to 1.6 \\
\hline $25-34$ & 2057 & 9.2 & 63.0 & 27.8 & \multicolumn{2}{|l|}{ ref } & \multicolumn{2}{|l|}{ ref } \\
\hline$\geq 35$ & 1098 & 6.8 & 67.2 & 26.0 & 0.7 & 0.5 to 1.2 & 1.0 & 0.8 to 1.3 \\
\hline \multicolumn{9}{|l|}{ Parity at delivery } \\
\hline Multiparous & 2156 & 8.3 & 63.6 & 28.1 & \multicolumn{2}{|l|}{ ref } & \multicolumn{2}{|l|}{ ref } \\
\hline Nulliparous & 1390 & 11.2 & 62.7 & 26.1 & 1.1 & 0.7 to 1.6 & 1.0 & 0.8 to 1.2 \\
\hline \multicolumn{9}{|l|}{ Multiple birth } \\
\hline No (singleton) & 2531 & 10.6 & 62.0 & 27.4 & \multicolumn{2}{|l|}{ ref } & \multicolumn{2}{|l|}{ ref } \\
\hline Yes (twins or more) & 1056 & 7.5 & 65.4 & 27.1 & 0.5 & 0.3 to 0.9 & 1.0 & 0.7 to 1.2 \\
\hline \multicolumn{9}{|l|}{ Mother's educational level } \\
\hline $\begin{array}{l}\text { Lower (ISCED levels 0-2: lower secondary } \\
\text { or lower) }\end{array}$ & 589 & 13.7 & 58.9 & 27.4 & 2.0 & 1.1 to 3.5 & 0.9 & 0.7 to 1.3 \\
\hline $\begin{array}{l}\text { Intermediate (ISCED levels 3-5: upper or post- } \\
\text { secondary, non-tertiary or short cycle tertiary) }\end{array}$ & 1474 & 9.7 & 64.0 & 26.3 & 1.4 & 0.9 to 2.2 & 0.8 & 0.7 to 1.1 \\
\hline $\begin{array}{l}\text { Higher (ISCED levels 6-8: bachelor degree or } \\
\text { higher) }\end{array}$ & 1478 & 6.3 & 66.3 & 27.4 & Ref & & Ref & \\
\hline Country of birth & & & & & & & & \\
\hline Native & 2857 & 8.9 & 63.5 & 27.6 & Ref & & Ref & \\
\hline European born & 238 & 7.7 & 63.9 & 28.4 & 0.9 & 0.4 to 2.0 & 0.8 & 0.5 to 1.2 \\
\hline Born outside Europe & 476 & 13.3 & 61.9 & 24.9 & 2.5 & 1.4 to 4.2 & 1.4 & 1.0 to 1.9 \\
\hline GA, completed weeks & & & & & & & & \\
\hline$<26$ & 305 & 5.5 & 53.9 & 40.6 & 0.2 & 0.1 to 0.4 & 0.3 & 0.2 to 0.5 \\
\hline $26-27$ & 657 & 6.0 & 54.2 & 39.9 & 0.2 & 0.1 to 0.4 & 0.5 & 0.4 to 0.6 \\
\hline $28-29$ & 937 & 6.3 & 66.1 & 27.6 & 0.3 & 0.2 to 0.5 & 0.7 & 0.6 to 0.9 \\
\hline $30-31$ & 1688 & 13.8 & 66.2 & 20.0 & Ref & & Ref & \\
\hline Small for $\mathrm{GA}^{* *}$ & & & & & & & & \\
\hline$<3$ centile & 766 & 7.7 & 62.0 & 30.2 & 0.5 & 0.3 to 0.7 & 0.7 & 0.5 to 0.9 \\
\hline $3-9$ centile & 417 & 11.0 & 59.3 & 29.6 & 1.0 & 0.6 to 1.6 & 0.7 & 0.5 to 0.9 \\
\hline$\geq 10$ centile & 2404 & 10.2 & 63.8 & 26.0 & Ref & & Ref & \\
\hline Severe neonatal morbidity $\dagger+$ & & & & & & & & \\
\hline No & 3141 & 10.4 & 63.5 & 26.1 & Ref & & Ref & \\
\hline Yes & 365 & 5.0 & 57.7 & 37.3 & 0.5 & 0.2 to 1.1 & 0.9 & 0.7 to 1.3 \\
\hline Bronchopulmonary dysplasia & & & & & & & & \\
\hline No & 3034 & 10.7 & 64.4 & 24.9 & Ref & & Ref & \\
\hline Yes & 466 & 3.8 & 53.8 & 42.4 & 0.4 & 0.2 to 0.8 & 0.6 & 0.5 to 0.9 \\
\hline Congenital anomaly & & & & & & & & \\
\hline No & 3292 & 9.9 & 62.7 & 27.4 & Ref & & Ref & \\
\hline Yes & 295 & 8.5 & 65.5 & 26.0 & 0.6 & 0.3 to 1.2 & 0.9 & 0.6 to 1.2 \\
\hline Child sex & & & & & & & & \\
\hline Male & 1914 & 10.0 & 59.3 & 30.7 & 0.9 & 0.6 to 1.3 & 0.7 & 0.6 to 0.9 \\
\hline Female & 1673 & 9.4 & 67.1 & 23.5 & Ref & & Ref & \\
\hline Country (region) & & & & & (ref san & ole mean) & (ref san & mean) \\
\hline Portugal (Lisbon, Northern Region) & 425 & 4.8 & 36.8 & 58.4 & 0.6 & 0.3 to 1.2 & 0.2 & 0.1 to 0.2 \\
\hline Belgium (Flanders) & 259 & 12.8 & 40.5 & 46.7 & 3.6 & 2.0 to 6.3 & 0.3 & 0.2 to 0.4 \\
\hline Netherlands (Central Eastern) & 146 & 6.3 & 52.2 & 41.5 & 1.7 & 0.7 to 4.1 & 0.5 & 0.3 to 0.7 \\
\hline $\begin{array}{l}\text { France (Burgundy, lle-de-France, Northern } \\
\text { Region) }\end{array}$ & 770 & 10.3 & 58.6 & 31.2 & 3.0 & 1.9 to 4.6 & 0.6 & 0.5 to 0.8 \\
\hline Denmark (Eastern Region) & 151 & 10.8 & 62.5 & 26.7 & 6.3 & 2.9 to 13.8 & 0.9 & 0.6 to 1.4 \\
\hline Sweden (Greater Stockholm) & 141 & 2.8 & 70.7 & 26.6 & 1.1 & 0.2 to 6.3 & 1.0 & 0.7 to 1.5 \\
\hline $\begin{array}{l}\text { UK (East Midlands, Northern, Yorkshire and } \\
\text { the Humber) }\end{array}$ & 419 & 13.6 & 69.4 & 17.0 & 10.9 & 6.1 to 19.4 & 1.9 & 1.4 to 2.7 \\
\hline Germany (Hesse, Saarland) & 266 & 21.5 & 65.4 & 13.0 & 21.1 & 11.3 to 39.4 & 1.9 & 1.2 to 3.1 \\
\hline Estonia (entire country) & 133 & 0.0 & 87.2 & 12.8 & 0.0 & 0.0 to 0.0 & 2.6 & 1.6 to 4.2 \\
\hline Italy (Emilia-Romagna, Lazio, Marche) & 691 & 4.5 & 83.2 & 12.3 & 4.5 & 2.3 to 8.7 & 2.5 & 1.9 to 3.3 \\
\hline Poland (Wielkopolska) & 186 & 13.4 & 75.7 & 10.9 & 18.9 & 9.4 to 38.3 & 2.9 & 1.8 to 4.8 \\
\hline
\end{tabular}

This study provides novel data on use of routine follow-up services after preterm birth based on a population-based design and standardised questions on follow-up from diverse European regions. Limits are reliance on parental recall and study attrition.

Children from socially disadvantaged families were more likely to never use follow-up services, corroborating previous 
studies. ${ }^{5}$ This is concerning, as these children are more vulnerable to the adverse neurodevelopmental consequences of preterm birth, and may benefit most from interventions. Variation between European countries in the percentage of children continuing follow-up at five persisted after accounting for perinatal risk factors, such as lower GA and neonatal morbidities. While differences are expected, given the heterogeneity in follow-up policies and programmes, the magnitude of these cross-country disparities, in tandem with marked social inequalities at follow-up entry, underscore the need for better evidence on optimal follow-up organisation and duration.

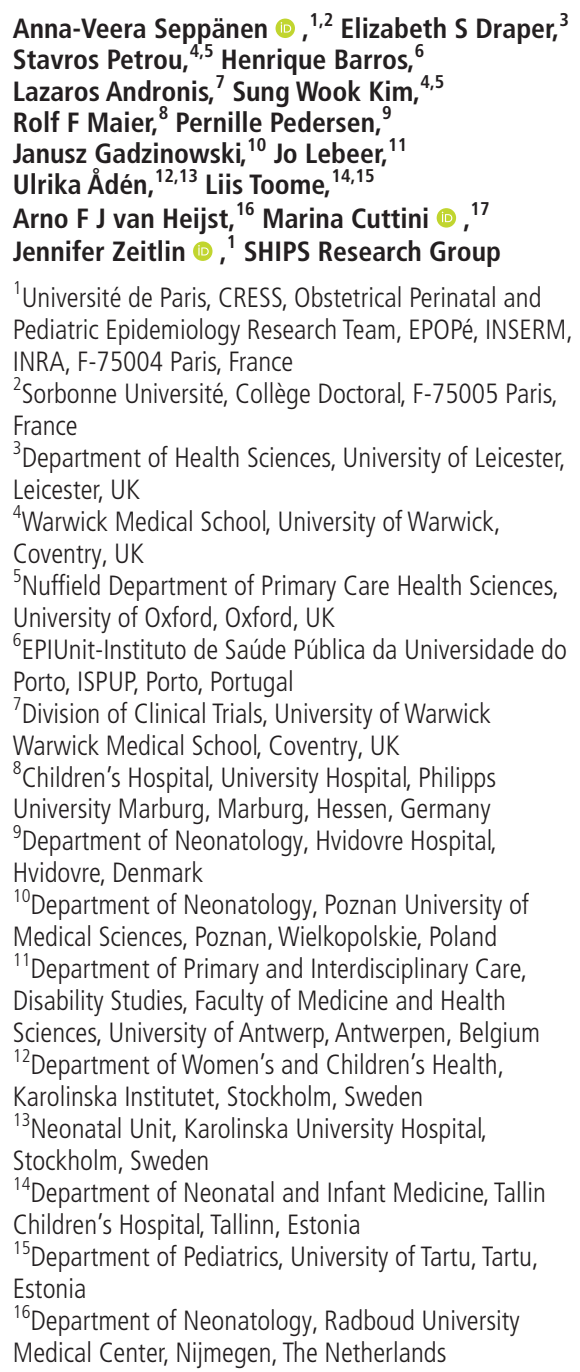

${ }^{2}$ Sorbonne Université, Collège Doctoral, F-75005 Paris, France

${ }^{3}$ Department of Health Sciences, University of Leicester, Leicester, UK

${ }^{4}$ Warwick Medical School, University of Warwick,

Coventry, UK

${ }^{5}$ Nuffield Department of Primary Care Health Sciences, University of Oxford, Oxford, UK

${ }^{6}$ EPIUnit-Instituto de Saúde Pública da Universidade do Porto, ISPUP, Porto, Portugal

${ }^{7}$ Division of Clinical Trials, University of Warwick

Warwick Medical School, Coventry, UK

${ }^{8}$ Children's Hospital, University Hospital, Philipps

University Marburg, Marburg, Hessen, Germany

${ }^{9}$ Department of Neonatology, Hvidovre Hospital, Hvidovre, Denmark

${ }^{10}$ Department of Neonatology, Poznan University of Medical Sciences, Poznan, Wielkopolskie, Poland

${ }^{11}$ Department of Primary and Interdisciplinary Care, Disability Studies, Faculty of Medicine and Health Sciences, University of Antwerp, Antwerpen, Belgium

${ }^{12}$ Department of Women's and Children's Health, Karolinska Institutet, Stockholm, Sweden

${ }^{13}$ Neonatal Unit, Karolinska University Hospital, Stockholm, Sweden

${ }^{14}$ Department of Neonatal and Infant Medicine, Tallin Children's Hospital, Tallinn, Estonia

${ }^{15}$ Department of Pediatrics, University of Tartu, Tartu, Estonia

${ }^{16}$ Department of Neonatology, Radboud University Medical Center, Nijmegen, The Netherlands

${ }^{17}$ Clinical Care and Management Innovation Research Area, Bambino Gesù Children's Hospital, IRCCS, Rome, Italy

Correspondence to Anna-Veera Seppänen, Université de Paris, CRESS, Obstetrical Perinatal and Pediatric Epidemiology Research Team, EPOPé, Inserm, INRA, F-75004 Paris, France; anna-veera.seppanen@inserm.fr

Twitter Lazaros Andronis @Epope_Inserm

Collaborators SHIPS Research Group: Belgium (J Lebeer, I Sarrechia, P Van Reempts, E Bruneel, E Cloet, A Oostra, E Ortibus); Denmark (K Boerch, P Pedersen); Estonia (L Toome, H Varendi, M Männamaa); France (PY Ancel, A Burguet, PH Jarreau, V Pierrat, A Nuytten); Germany (RF Maier, M Zemlin, B Misselwitz, L Wohlers,) Italy (M Cuttini, I Croci, V Carnielli, G Ancora, G Faldella, F Ferrari); The Netherlands (A van Heijst, C Koopman-Esseboom); Poland (J Gadzinowski, J Mazela, A Montgomery, T Pikuła) Portugal (H Barros, R Costa, C Rodrigues); Sweden (U Aden); United Kingdom (ES Draper, A Fenton, SJ Johnson); EFCNI (S Mader, N Thiele, JM Pfeil); Health Economics team (S Petrou, SW Kim, L Andronis); Inserm Coordination (J Zeitlin, A M Aubert, C Bonnet, R El Rafei, AV Seppänen).

Contributors A-VS, ESD, SP, HB, LA, SWK, RFM, $P P, J G, J L, U A, L T, A F J v H, M C$, JZ and the Screening to Improve Health in Very Preterm Infants (SHIPS) Research Group made substantial contributions to the conception and design and acquisition of data. A-VS and IZ analysed the data. A-VS, ESD, SP, HB, LA, SWK, RFM, PP, JG, JL, UA, LT, AFJVH, MC and JZ contributed to interpretation of data, drafting the letter, revising it critically for important intellectual content, and approved the final version to be published. Members of the SHIPS research group approved the final version to be published.

Funding The research received funding from the European Union's Horizon 2020 Research and Innovation Programme (under grant agreement number 633 724). Additional funding was received in the following regions: France: French National Institute of Public Health Research (IRESP TGIR 2009-01 programme)/Institute of Public Health and its partners (the French Health Ministry, the National Institute for Health and Medical Research), the National Institute of Cancer and the National Solidarity Fund for Autonomy), the National Research Agency through the French EQUIPEX programme of investments for the future (grant number ANR-11-EQPX-0038) and the PremUp Foundation; Poland: 2016-2019 allocation of funds for international projects from the Polish Ministry of Science and Higher Education; Sweden: Swedish Medical Research Council (grant number 2017-03043) and the regional agreement on medical training and clinical research between Stockholm County Council and the Karolinska Institutet (grant number: ALF SLL 20170243). Anna-Veera Seppänen has a doctoral contract funded by Sorbonne Université Collège Doctoral, Paris, France.

Competing interests None declared.

Patient consent for publication Not required.

Ethics approval Ethics approvals were obtained locally and for the European database in France.
Provenance and peer review Not commissioned: internally peer reviewed.

$$
\text { OPEN ACCESS }
$$

Open access This is an open access article distributed in accordance with the Creative Commons Attribution Non Commercial (CC BY-NC 4.0) license, which permits others to distribute, remix, adapt, build upon this work non-commercially, and license their derivative works on different terms, provided the original work is properly cited, appropriate credit is given, any changes made indicated, and the use is non-commercial. See: http://creativecommons.org/ licenses/by-nc/4.0/

(c) Author(s) (or their employer(s)) 2022. Re-use permitted under CC BY-NC. No commercial re-use. See rights and permissions. Published by BMJ.

$$
\text { (A) Check for updates }
$$

To cite Seppänen A-V, Draper ES, Petrou S, et al. Arch Dis Child Fetal Neonatal Ed 2022;107:F113-F114.

Accepted 25 January 2021

Published Online First 10 February 2021

Arch Dis Child Fetal Neonatal Ed 2022;107:F113F114.

doi:10.1136/fetalneonatal-2020-320823

\section{ORCID iDs}

Anna-Veera Seppänen http://orcid.org/0000-00015615-0639

Marina Cuttini http://orcid.org/0000-0002-3284-6874 Jennifer Zeitlin http://orcid.org/0000-0002-9568-2969

\section{REFERENCES}

1 Haute Autorité de Santé. Recommandation de bonne pratique, troubles du neurodéveloppement: Repérage et orientation des enfants risque. Paris: Haute Autorité de Santé (HAS), 2020.

2 NICE. NICE guideline: developmental follow-up of children and young people born preterm. London: National Institute for Health and Care Excellence (NICE), 2017.

3 Gemeinsamer Bundesausschuss. Richtlinie des Gemeinsamen Bundesausschusses über Maßnahmen zur Qualitätssicherung der Versorgung von Früh- und Reifgeborenen gemäß \& 136 Absatz 1 Nummer 2 SGB $V$ in Verbindung mit § 92 Abs. 1 Satz 2 Nr. 13 SGB V (Qualitätssicherungs-Richtlinie Früh- und Reifgeborene/ QFR-RL). Bundesanzeiger, 2020: 2005 S. 15-684.

4 Zeitlin J, Maier RF, Cuttini M, et al. Cohort profile: effective perinatal intensive care in Europe (EPICE) very preterm birth cohort. Int J Epidemio/ 2020;49:372-86

5 Hintz SR, Gould JB, Bennett MV, et al. Referral of very low birth weight infants to high-risk follow-up at neonatal intensive care unit discharge varies widely across California. J Pediatr 2015;166:289-95. 